\title{
Suppression of secondary hyperparathyroidism in children with chronic renal failure by high dose phosphate binders: calcium carbonate versus aluminium hydroxide
}

\author{
R H K MAK, C TURNER, THEA THOMPSON, HELEN POWELL， G B HAYCOCK, C CHANTLER
}

\begin{abstract}
Secondary hyperparathyroidism was suppressed over a period of one year in 12 children with chronic renal failure by using a regimen of mild dietary phosphate restriction and high dose phosphate binders. The patients were randomised to receive either aluminium hydroxide or calcium carbonate by mouth for six months and then crossed over to the other medication. Vitamin D (dihydrotachysterol) dosage was unchanged. Serum parathyroid hormone concentrations were reduced to within the normal range, urinary cyclic adenosine monophosphate values fell, plasma phosphate concentrations decreased, and the theoretical renal phosphate threshold increased significantly. Transiliac bone biopsy findings improved in four patients with adequate suppression of parathyroid hormone concentrations, deteriorated in two patients who were not compliant, and did not change in five patients in whom initial bone disease was mild. Growth velocity improved significantly. There was no difference in the clinical response, biochemical changes, or incidence of complications during treatment with the two agents.

In view of the risk of aluminium toxicity the use of high dose calcium carbonate with dietary phosphate restriction and vitamin $D$ supplementation is recommended in the control of secondary hyperparathyroidism in children with chronic renal failure.
\end{abstract}

Evelina Children's Hospital, Guy's Hospital, London SE1 9RT R H K MAK, PHD, MRCP, Wellcome lecturer C TURNER, BSC, biochemist

THEA THOMPSON, BSC, research dietitian HELEN POWELL, MSC, research dietitian

G B HAYCOCK, FRCP, consultant paediatrician

C CHANTLER, MD, FRCP, professor of paediatric nephrology

Correspondence to: Professor Chantler.

\section{Introduction}

Secondary hyperparathyroidism is common in end stage renal disease and may cause disabling bone problems, growth retardation, and other complications. ${ }^{1-3}$ Although the role of dietary phosphate in the pathogenesis of secondary hyperparathyroidism in experimental uraemia is well established, 4-6 successful long term suppression of secondary hyperparathyroidism by dietary phosphate restriction has not been achieved in adults or children with chronic renal failure. Very low phosphate diets are unpalatable, and oral aluminium compounds used to bind dietary phosphate to prevent absorption carry a risk of aluminium toxicity, particularly in young children. ${ }^{78}$ Calcium carbonate has been used as an alternative phosphate binder, ${ }^{910}$ but long term clinical trials have not been reported. We studied the use of high dose phosphate binders and mild dietary phosphate restriction for the suppression of secondary hyperparathyroidism and compared aluminium hydroxide and calcium carbonate as phosphate binders in a randomised crossover study of children with chronic renal failure. The effects of the correction of secondary hyperparathyroidism on growth, renal function, and anaemia are reported.

\section{Patients and methods}

Twelve children aged 5-15 years (mean 11 years) in stable chronic renal failure were studied. They were selected for the study so that both mild renal insufficiency and severe chronic renal failure were represented. Table I summarises the clinical details of the children at the initial assessment.

The children had previously received reduced dietary protein and phosphate intakes with energy supplementation in the form of glucose polymer (Caloreen), and aluminium hydroxide had been given as a phosphate binder (mean dosage $1.3 \mathrm{~g} /$ day) with vitamin $D$ supplementation as dihydrotachysterol $\left(0.25 \mathrm{mg} / \mathrm{m}^{2} /\right.$ day; this form of vitamin $D$ was routinely used in such children when the trial began, although now we prefer to use $1 \alpha$ or 1,25 -dihydroxycholecalciferol). Table I shows the other medications used.

Initially the aluminium hydroxide was withdrawn while the patients continued with their previous diets for three months. Three day prospective dietary assessments with accurate weighed records of all food items consumed were performed monthly over a weekend 
(Friday, Saturday, Sunday) throughout the study, a computer program of food tables being used to analyse the results. This method of dietary assessment agrees closely with chemical analysis of duplicate samples of food consumed (for protein, $\mathrm{r}=0.96 ; 95 \%$ confidence limits $-4 \%$ to $+16 \%) .{ }^{11}$ Urine and faeces were collected over the same period. Blood samples were taken on the morning after completing the three day collections. Tubular reabsorption of phosphate was calculated from the formula $1-\left({ }^{u} \mathrm{PO}_{4} / \mathrm{pPO}_{4} \times{ }^{\mathrm{p} C r} /{ }^{\mathrm{C}} \mathrm{Cr}\right)$, where ${ }^{\mathrm{u} P \mathrm{PO}_{4}}=$ urinary phosphate, $\mathrm{PPO}_{4}=$ plasma phosphate, ${ }^{u} \mathrm{Cr}=$ urinary creatinine, and $\mathrm{p} C r=$ plasma creatinine. Theoretical phosphate threshold was calculated from tubular reabsorption of phosphate and plasma phosphate values using Bijvoet's nomograms. ${ }^{12}$ In a separate series of experiments we found that estimation of theoretical phosphate threshold from 24 hour urine specimens compared well with the method described by Bijvoet, which utilises three hour urine collections obtained in the morning while fasting and during a moderate diuresis $^{13}(n=40 ; r=0.87 ; p<0.001)$.

After the initial three months the diet was stabilised with moderate phosphorus restriction while maintaining protein intake at the previous level. The children were advised to reduce the intake of dairy protein, especially skimmed milk, cheese, and milk chocolates. Low phosphorus milk substitutes and special low phosphorus baking powder were provided. Food tables were given so that food items with a low phosphorus content could be chosen-for example, fine cereals contain less phosphate than cereals with bran. If the child had a particular liking for a food with a high phosphorus content it was allowed in moderation and the dosage of the phosphate binder used increased accordingly.

The patients were randomly allocated to receive either aluminium hydroxide or calcium carbonate as the phosphate binder. The dosage was increased to reduce the plasma phosphate concentration to the lower limit of the normal range and the children seen fortnightly until this was achieved. Further adjustments to the dosage of the phosphate binder were made from the monthly dietary assessment and based on the plasma phosphate, tubular reabsorption of phosphate, theoretical phosphate threshold, and serum parathyroid hormone results with the intention of maximising the tubular reabsorption of phosphate and theoretical phosphate threshold and reducing the parathyroid hormone concentration as far as possible to normal. Vitamin D supplementation in the form of dihydrotachysterol was provided for al children and the dosage was not changed for the six months before entry to the study and throughout the 15 months of the study period. No change in other medications occurred during the study period.

Parathyroid hormone was measured by radioimmunoassay with an antibody (BW 211/32) directed towards the whole molecule with emphasis on the $\mathrm{N}$ terminal. ${ }^{14}$ Urinary cyclic adenosine monophosphate was measured by competitive protein binding assay (Amersham International). ${ }^{15}$ Plasma and urinary calcium, phosphate, alkaline phosphatase, and creatinine values were measured by a multichannel autoanalyser (Vickers). Ten per cent hydrochloric acid $(50 \mathrm{ml})$ was added to each urine bottle to prevent phosphorus precipitating during the collection. Faeces were digested with concentrated sulphuric acid using a selenium catalyst and assayed for phosphate using the phosphomolybdate reaction. ${ }^{16}$

Transiliac bone biopsy was performed in all patients with an $8 \mathrm{~mm}$ Bordier needle under a short general anaesthetic before and after 12 months of treatment. Qualitative analysis was performed blindly by a single observer and grades of definite improvement, deterioration, and no appreciable change given. Glomerular filtration rate was measured by the chromium-51 edetic acid method using single exponential analysis. ${ }^{17}$ Estimated glomerular filtration rate ${ }^{18}$ was calculated from the formula $40 \times$ height $(\mathrm{cm}) /$ plasma creatinine $(\mu \mathrm{mol} / \mathrm{l})$. Height was measured with the same Stadiometer by the same single observer throughout and analysed using standard growth charts.

Statistical analysis was by paired Student's $t$ test and the least squares method of linear regression. All values are expressed as means and standard error (SE). The study was approved by the Guy's Hospital ethical committee and informed consent obtained from the patients and parents before inclusion in the study.

\section{Results}

Table I gives the details of the 12 children studied and the results at the end of the initial three month period; all the children had raised concentrations of serum immunoreactive parathyroid hormone. Figures 1 and 2 and table II summarise the subsequent biochemical and dietary changes which occurred. Parathyroid hormone concentrations were reduced to within the normal range for children (less than $450 \mathrm{ng} / \mathrm{l}$ ) by the end of six months of treatment. Urinary excretion of cyclic adenosine monophosphate (normal range $120-350 \mu \mathrm{mol} / \mathrm{mol}$ creatinine; 370-1075 $\mu \mathrm{g} / \mathrm{g}$ creatinine), an index of parathyroid hormone activity, also fell significantly. Two of the children were less compliant towards the end of the study, and this was reflected by their

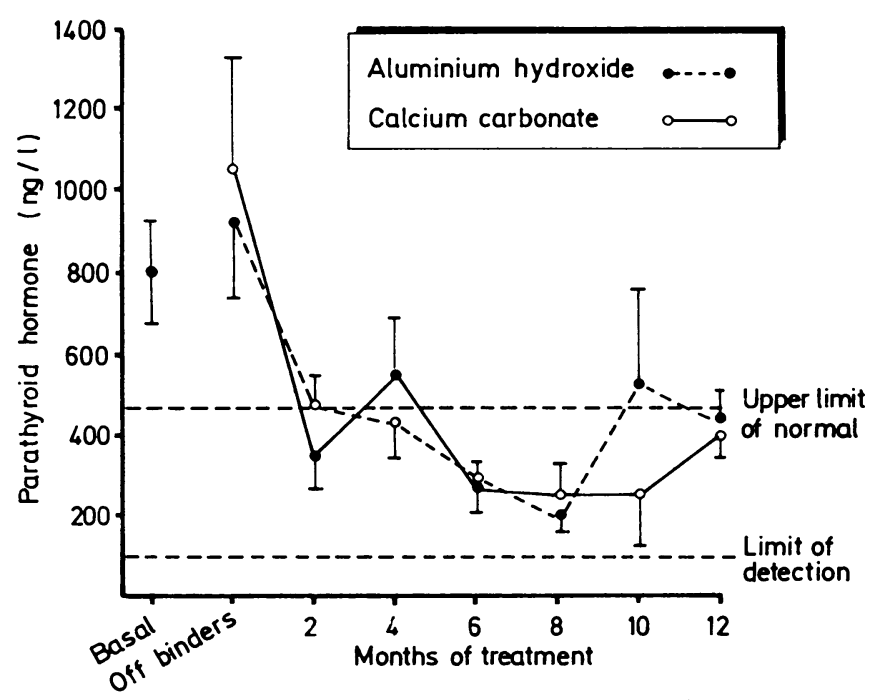

FIG 1 - Changes in serum parathyroid hormone concentrations after institution of low phosphate diet with high dose phosphate binders (aluminium hydroxide $(O)$ and calcium carbonate $(O)$ ). Points are means. Bars are SE.

\begin{tabular}{|c|c|c|c|c|c|c|c|c|c|c|c|c|}
\hline $\begin{array}{l}\text { Case } \\
\text { No }\end{array}$ & $\underset{\text { (years) }}{\text { Age }}$ & Sex & Diagnosis & $\begin{array}{l}\text { Duration of } \\
\text { renal disease } \\
\text { (years) }\end{array}$ & $\begin{array}{l}\text { Pubertal } \\
\text { state } \\
\text { (Tanner's } \\
\text { score) }\end{array}$ & $\begin{array}{c}\text { Height } \\
\text { standard } \\
\text { deviation } \\
\text { score } \\
\text { (bone age)* }\end{array}$ & $\begin{array}{c}\text { Glomerular } \\
\text { filtration } \\
\text { rate } \\
(\mathrm{ml} \mathrm{min} \\
\left.1.73 \mathrm{~m}^{2}\right)\end{array}$ & $\underset{(\text { mmolil) }}{\text { Urea }}$ & $\begin{array}{l}\text { Parathyroid } \\
\text { hormone } \\
(\text { ng } 11)\end{array}$ & $\begin{array}{l}\text { Theoretical } \\
\text { phosphate } \\
\text { threshold } \\
\text { (mmol l) }\end{array}$ & $\underset{(\mathrm{g}: 1)}{\text { Haemoglobin }}$ & $\begin{array}{l}\text { Medications (other than } \\
\text { aluminium hydroxide, } \\
\text { vitamin D) }\end{array}$ \\
\hline$\frac{1}{2}$ & $\begin{array}{l}5 \\
6\end{array}$ & $\begin{array}{l}\mathrm{F} \\
M\end{array}$ & $\begin{array}{l}\text { Neonatal cortical necrosis } \\
\text { Haemolytic uraemic syndrome }\end{array}$ & $\begin{array}{l}5 \\
1\end{array}$ & $\begin{array}{l}1 \cdot 1 \\
1.1\end{array}$ & $\begin{array}{l}+2.60 \\
+0.57\end{array}$ & 31 & $\begin{array}{l}18 \cdot 8 \\
22.2\end{array}$ & $\begin{array}{r}1500 \\
980\end{array}$ & $\begin{array}{l}0.62 \\
0.95\end{array}$ & $\begin{array}{l}94 \\
79\end{array}$ & $\begin{array}{l}\text { Sodium bicarbonate } \\
\text { Captopril, frusemide, }\end{array}$ \\
\hline 3 & 7 & $M$ & Obstructive uropathy & 7 & $1 \cdot 1$ & -2.83 & 10 & $35 \cdot 8$ & 1600 & $0 \cdot 17$ & 96 & $\begin{array}{l}\text { Sodium bicarbonate, co- } \\
\text { trimoxale, ferrous sulphate }\end{array}$ \\
\hline $\begin{array}{l}4 \\
5 \\
6\end{array}$ & $\begin{array}{l}10 \\
10 \\
10\end{array}$ & $\underset{\mathrm{F}}{\mathrm{F}}$ & $\begin{array}{l}\text { Obstructive uropathy } \\
\text { Reflux dysplasia } \\
\text { Reflux nephropathy }\end{array}$ & $\begin{array}{r}2 \\
10 \\
1\end{array}$ & $\begin{array}{l}1 \cdot 1 \\
1.1 \\
1.1\end{array}$ & $\begin{array}{l}-2 \cdot 10 \\
-1 \cdot 78 \\
-1 \cdot 40\end{array}$ & $\begin{array}{r}35 \\
32 \\
9\end{array}$ & $\begin{array}{l}13.4 \\
17.9 \\
25.1\end{array}$ & $\begin{array}{r}750 \\
750 \\
2600\end{array}$ & $\begin{array}{l}0.68 \\
1.08 \\
0.38\end{array}$ & $\begin{array}{l}125 \\
124 \\
73\end{array}$ & $\begin{array}{l}\text { Co-trimoxazole } \\
\text { Captopril, prazosin, frusemide, } \\
\text { propranolol, cephalexin, }\end{array}$ \\
\hline 7 & 10 & $\mathrm{~F}$ & Reflux nephropathy & 3 & $2 \cdot 2$ & +0.70 & 22 & 120 & 720 & 0.25 & 112 & $\begin{array}{l}\text { Sodium bicarbonate, prazosin, } \\
\text { frusemide, propranolol, } \\
\text { nitrofurantoin }\end{array}$ \\
\hline $\begin{array}{l}8 \\
9\end{array}$ & $\begin{array}{l}13 \\
13\end{array}$ & $\underset{M}{\mathrm{~F}}$ & $\begin{array}{l}\text { Juvenile nephronophthisis } \\
\text { Haemolytic uraemic syndrome }\end{array}$ & $\begin{array}{l}5 \\
1\end{array}$ & $\begin{array}{l}3 \cdot 3 \\
3 \cdot 3\end{array}$ & $\begin{array}{l}+0.20 \\
-0.95\end{array}$ & $\begin{array}{l}15 \\
17\end{array}$ & $\begin{array}{l}18.5 \\
29.8\end{array}$ & $\begin{array}{l}1050 \\
1000\end{array}$ & $\begin{array}{l}0.58 \\
1.22\end{array}$ & $\begin{array}{r}108 \\
90\end{array}$ & $\begin{array}{l}\text { Captopril, prazosin, } \\
\text { hydralazine, frusemide, } \\
\text { propranolol }\end{array}$ \\
\hline 10 & 13 & $\mathrm{M}$ & Interstitial nephritis & 1 & $4 \cdot 4$ & -0.93 & 45 & $9 \cdot 2$ & 640 & 0.55 & 112 & $\begin{array}{l}\text { Prednisolone, propranolol, } \\
\text { ethambutol, rifampicin, } \\
\text { isoniazid, pyridoxine }\end{array}$ \\
\hline 11 & 14 & $M$ & Mesangial capillary glomerulonephritis & 9 & 4.4 & -0.50 & 16 & $31 \cdot 1$ & 1200 & $0 \cdot 82$ & 105 & $\begin{array}{l}\text { Prednisolone, prazosin, } \\
\text { frusemide, azathioprine, } \\
\text { propranolol, Slow-K, } \\
\text { dipyridamole, warfarin }\end{array}$ \\
\hline 12 & 14 & $\mathbf{M}$ & Neonatal cortical necrosis & 14 & $4 \cdot 4$ & -0.12 & 8 & 258 & 1800 & 0.82 & 95 & $\begin{array}{l}\text { Frusemide, propranolol, } \\
\text { lactulose }\end{array}$ \\
\hline
\end{tabular}



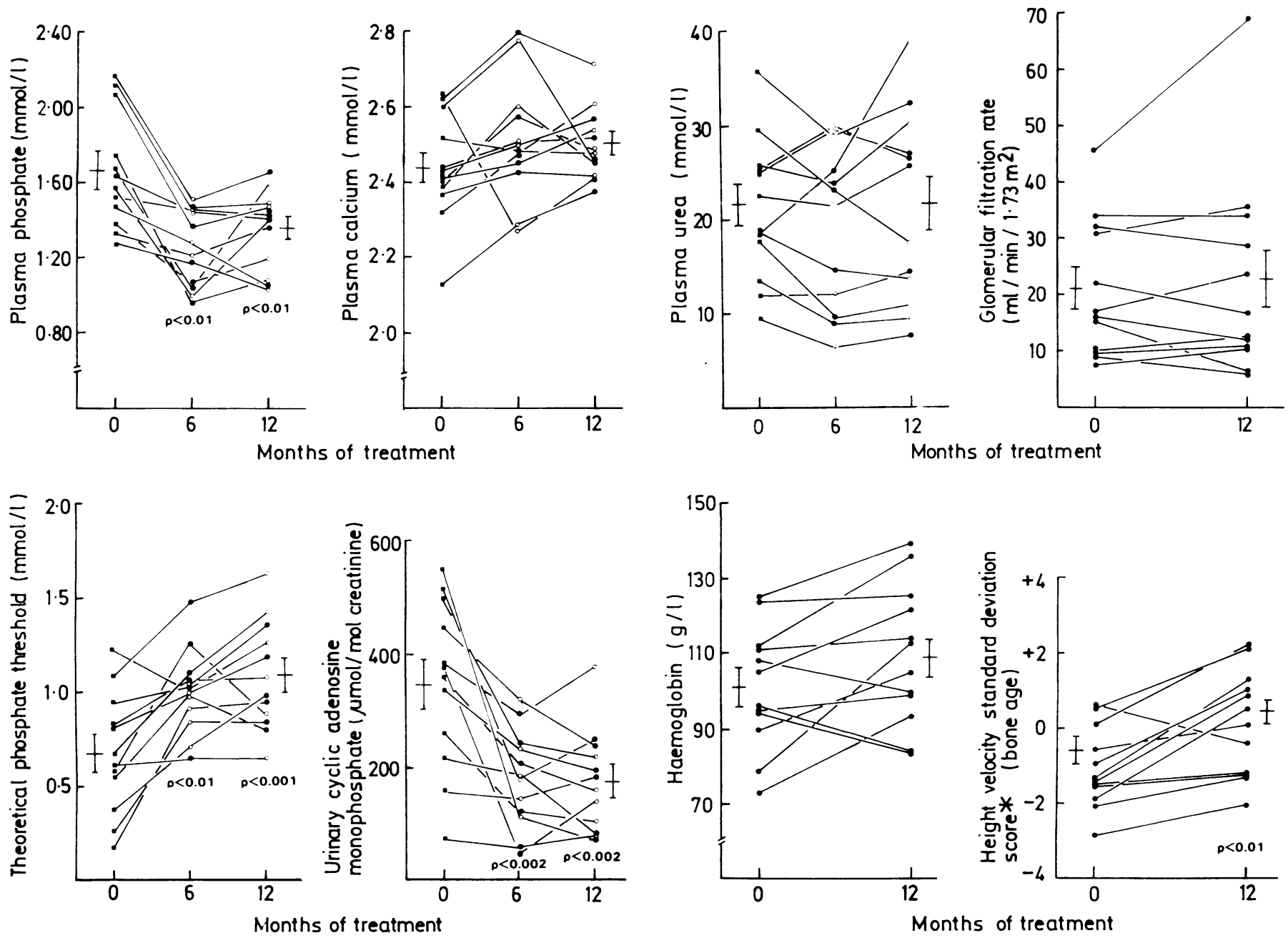

FIG 2-Changes in values observed in 12 children during treatment with aluminium hydroxide (O) and calcium carbonate ( $O$ ). Bars are means and SE.

* Expressed as number of standard deviations above or below mean height of normal children of same bone age.

Conversion: SI to traditional units-Phosphate: $1 \mathrm{mmol} / 1 \approx 3.1 \mathrm{mg} / 100 \mathrm{ml}$. Calcium: $1 \mathrm{mmol} / 1 \approx 4 \mathrm{mg} / 100 \mathrm{ml}$. Theoretical phosphate threshold: $1 \mathrm{mmol} / 1$ glomerular filtrate $\approx 3.1 \mathrm{mg} / 1 \mathrm{glomerular}$ filtrate. Urinary cyclic adenosine monophosphate: $1 \mu \mathrm{mol} / \mathrm{mol} \mathrm{creatinine} \approx 3 \cdot 07 \mu \mathrm{g} / \mathrm{g} \mathrm{creatinine}$. Urea: $1 \mathrm{mmol} / 1 \approx 6$ $\mathrm{mg} / 100 \mathrm{ml}$.

TABLE II-Dietary changes. Values are means ( $S E$ in parentheses)

\begin{tabular}{llll}
\hline & \multicolumn{1}{c}{ Basal } & 6 months & 12 months \\
\hline $\begin{array}{l}\text { Phosphate (mmol/day) } \\
\text { Calcium (mmol/day) }\end{array}$ & $\begin{array}{ll}32 \cdot 2(2 \cdot 5) \\
\text { Protein (\% minimum recommended }\end{array}$ & $\begin{array}{l}24 \cdot 5(2 \cdot 15)^{*} \\
\text { intake) }\end{array}$ & $26 \cdot 5(1 \cdot 4)$ \\
$\begin{array}{l}\text { Energy (\%ocommended daily } \\
\text { allowance) }\end{array}$ & $142(11)$ & $135(7)$ & $136(5)$ \\
\hline
\end{tabular}

*p $<0.05$ compared with basal value.
Conversion: SI to traditional units-Phosphate: $1 \mathrm{mmol} \approx 31 \mathrm{mg}$. Calcium: 1 $\mathrm{mmol} \approx 40 \mathrm{mg}$.

plasma phosphate, theoretical reabsorption of phosphate, and serum parathyroid hormone values.

The biochemical changes at the end of six months of treatment with either calcium carbonate or aluminium hydroxide were not significantly different apart from higher serum aluminium concentrations during treatment with aluminium hydroxide $(1 \cdot 1$ (SE 0.2$) v 3.3(0.5) \mu \mathrm{mol} / 1$; $3.0(0.6) v 9.0(1.3) \mu \mathrm{g} / 100 \mathrm{ml})(\mathrm{p}<0.001)$. Faecal and urinary phosphorus excretion expressed as a percentage of intake was not different during treatment with calcium carbonate (faecal 52 (SE 7)\%; urinary $30(4) \%$ ) and aluminium hydroxide $(61(7) \% ; 25(4) \%)$. Dosage of aluminium hydroxide was much higher at the end of treatment $(5.8$ (SE 0.8) g/day) compared with initial conventional doses $(1.3(0.5)$ $\mathrm{g} /$ day). Dosage of calcium carbonate was $3.4(\mathrm{SE} 0 \cdot 6) \mathrm{g}$ at the end of treatment.

Eleven of the 12 repeat bone biopsy specimens were technically satisfactory. Mild to moderate features of osteitis fibrosa with no osteomalacia were present in all the specimens at the beginning of the study. Osteitis fibrosa definitely improved in four patients (mean parathy- roid hormone concentration: before 1300 (SE 450), after 430 (140) $\mathrm{ng} / \mathrm{l}$ ), deteriorated in two (mean parathyroid hormone concentrations: before 1300 (280), after 880 (130) ng/l), and did not change in five (mean parathyroid hormone concentration: before 1150 (210), after $300(80) \mathrm{ng} / \mathrm{l})$. No osteomalacia was apparent after treatment. The two patients in whom bone disease worsened were those who were less compliant with their phosphate control. Plasma phosphate concentration at the end of the study was $1.6 \mathrm{mmol} / 1(5.0 \mathrm{mg} / 100 \mathrm{ml})$ in both patients, whereas the mean for the rest of the group was 1.25 (SE $0.05) \mathrm{mmol} / 1(3.9(0.15) \mathrm{mg} / 100 \mathrm{ml})$. Total phosphate excretion in the two non-compliant patients was similar to the others, but urine phosphate excretion was raised $(59 \%$ and $81 \%$ compared with a mean of 28 (SE 4$) \%$ for the other patients) and faecal phosphate excretion was low $(34 \%$ and $35 \%$, mean for group $58(7) \%$ ).

Significant increases in growth velocity standard deviation scores calculated according to bone age $(-0.83$ (SE 0.32$) v+0.65(0.42)$; $\mathrm{p}<0.01)$ and chronological age $(-0.82(0.31) v 0.31(0.39) ; \mathrm{p}<0.01)$ were observed before and after 12 months of treatment. Glomerular filtration rate as measured using edetic acid showed no significant changes during treatment (21 (SE 4) $v 23(5) \mathrm{ml} / \mathrm{min} / 1.73 \mathrm{~m}^{2}$ ). In 10 patients in whom previous data were available there was no significant change in estimated glomerular filtration rate one year before (28.1 (SE 3.1$) \mathrm{ml} / \mathrm{min} / 1.73 \mathrm{~m}^{2}$ ), at the beginning $(26.7(4.1) \mathrm{ml} /$ $\left.\mathrm{min} / 1.73 \mathrm{~m}^{2}\right)$, and at the end $\left(26.4(4.8) \mathrm{ml} / \mathrm{min} / 1.73 \mathrm{~m}^{2}\right)$ of the study. Mean haemoglobin concentration (101 (SE 5) $v 109$ (5) $\mathrm{g} / \mathrm{l}$ ) did not alter before and after 12 months of treatment.

Side effects included transient periods of hypercalcaemia and hypophosphataemia, which were easily reversed by reducing the dosage of phosphate binder. There was no significant difference in the incidence of side effects during treatment with calcium carbonate or aluminium hydroxide. 


\section{Discussion}

Phosphate retention in uraemia is implicated in the development of secondary hyperparathyroidism and in alterations in the metabolism of vitamin D. An increase in plasma phosphate concentration as the glomerular filtration rate falls is associated with a reduction in the plasma concentration of ionised calcium with stimulation of parathyroid hormone, and in addition phosphorus mediated suppression of renal 25-hydroxyvitamin $\mathrm{D}_{3} 1 \alpha$-hydroxylase leads to a decrease in the plasma concentration of 1,25-dihydroxyvitamin $\mathrm{D}_{3}$, which reduces both the gut absorption and bone reabsorption of calcium, also leading to stimulation of parathyroid hormone release. ${ }^{19}$ With mild renal insufficiency the increase in parathyroid hormone is enough to return the plasma phosphate concentration to normal, but severe chronic renal failure is associated with a rise in the plasma phosphate value, which may result in a high calcium $\times$ phosphate product, leading to nephrocalcinosis and rapid deterioration of renal function. ${ }^{20}$ In experiments in dogs secondary hyperparathyroidism was prevented by limiting phosphate intake in proportion to the reduction in renal function in conjunction with supplementation with vitamin D. ${ }^{21}$ In addition, restriction of dietary phosphate in uraemic rats led to increased survival and a reduction in renal damage. ${ }^{22}$

Low phosphate diets are unpalatable and only short term studies, limited to 60 days, in adults have been reported..$^{23}$ In four patients with mild chronic renal failure dietary phosphate restriction resulted in correction of secondary hyperparathyroidism, increased gastrointestinal absorption of calcium, and improved bone histological appearances with no change in plasma calcium, phosphate, or phosphate balance. Phosphate binders have been used extensively to prevent dietary phosphate absorption. Biswas et al studied the short term effects of aluminium hydroxide in adults with preterminal chronic renal failure, but, whereas serum phosphate concentrations fell with a rise in total and ionised calcium, there was no reversal of secondary hyperparathyroidism. ${ }^{24}$ In this study, as indeed in routine clinical practice, the serum phosphate concentration was kept at the upper limit of the normal range while the plasma calcium concentrations were at the lower limit of the normal range in order to prevent a rise in the calcium $\times$ phosphate product with the risk of nephrocalcinosis. Probably, however, when secondary hyperparathyroidism is established a higher plasma ionised calcium concentration is required to initiate suppression, ${ }^{25}$ and therefore it is logical to reduce the plasma phosphate concentration to the lower end of the normal range while allowing the plasma calcium concentration to rise. Reduction in phosphate retention will increase $1 \alpha$-hydroxylation of 25 -hydroxyvitamin $\mathrm{D}_{3}$ in the remnant kidney. ${ }^{19}$ In our study suppression of established secondary hyperparathyroidism was achieved by a simple dietary regimen of avoiding high phosphate foods in conjunction with much larger dosages of phosphate binders than are used conventionally.

Aluminium toxicity with encephalopathy and severe osteodystrophy has been reported in children with uraemia in whom the only major source of aluminium intake was from the gastrointestinal absorption of phosphate binders containing aluminium. ${ }^{826-28}$ Moriniere et al gave calcium carbonate to adult uraemic patients receiving haemodialysis and obtained satisfactory control of hyperphosphataemia and hyperparathyroidism with a reversal of hyperaluminaemia which had resulted from treatment with aluminium hydroxide. ${ }^{10}$ The possibility that increased calcium absorption may lead to hypercalcaemia causes concern, but it would seem reasonable to substitute calcium carbonate for aluminium hydroxide after initial control of plasma phosphate concentration has been achieved. In our study episodes of hypercalcaemia were as common with aluminium hydroxide as with calcium carbonate and occurred only after several months of treatment, perhaps due to altered vitamin D metabolism resulting from control of phosphate retention.

The bone biopsy changes corresponded well to the clinical response. Definite improvement of bone disease occurred in four patients in whom suppression of hyperparathyroidism was adequate. Although the histological picture was not normal at the end of 12 months of treatment, this represented only six months of adequate suppression of parathyroid hormone values. Bone disease deteriorated in two patients who were less compliant, and the remaining five patients with no appreciable change did not have severe degrees of bone disease at the beginning of the study.

The improved growth of the children was encouraging, but since many of the children were entering puberty the results should be interpreted cautiously. Correction of hyperparathyroidism has been reported to improve growth in children receiving haemodialysis, but control studies are not available. ${ }^{29}$ Severe renal osteodystrophy contributes to growth retardation in advanced renal failure, but milder degrees of bone disease have not been shown to correlate with growth failure. ${ }^{30} 31$ Though we have shown that it is possible to suppress secondary hyperparathyroidism, at least over a 12 month period, it is not certain that such suppression can be maintained over a longer period. It would seem advisable to attempt to prevent the development of secondary hyperparathyroidism by control of phosphate absorption early in the development of renal insufficiency, particularly in very young children. In this respect the simple biochemical determinations such as plasma phosphate concentration and fractional phosphate excretion used in this study are easily applied and generally available.

Renal function did not change appreciably during the 15 months of the study; nevertheless, while this was encouraging, no conclusion about the effect of secondary hyperparathyroidism on renal function can be drawn because glomerular filtration rate as estimated from the plasma creatinine concentration was not significantly different 12 months before the study started in the 10 patients in whom data were available.

In conclusion, secondary hyperparathyroidism was suppressed over 12 months in children with preterminal chronic renal failure using a regimen of mild dietary phosphate restriction and high dose phosphate binders. Calcium carbonate was as effective as aluminium hydroxide as a phosphate binder and an improvement in growth was noted. The regimen was well tolerated with few and easily reversible side effects. In view of the risk of aluminium toxicity we recommend that high dose calcium carbonate should be used as the phosphate binder in patients with chronic renal failure after initial reduction of plasma phosphate with a low phosphate diet and aluminium hydroxide. We suggest that control of secondary hyperparathyroidism should be initiated early in the development of chronic renal failure when a definite rise in plasma parathyroid hormone concentration is detected or the tubular reabsorption of phosphate falls below normal. In children this may occur when the glomerular filtration rate falls below $45 \mathrm{ml} / \mathrm{min} / 1.73 \mathrm{~m}^{2}$.

We are grateful to Dr Juliet Compston, St Thomas's Hospital, London, for the assessment of bone biopsy specimens and help with the bone biopsy technique. We thank Dr P Smith, Newcastle Royal Infirmary, for performing the serum aluminium estimations. The study was supported by the Children Nationwide Medical Research Fund (National Medical Research Fund).

\section{References}

1 Slatopolsky E, Martin K, Hruska K. Parathyroid hormone metabolism and its

passry SG Goldstein DA. The search for uremic toxin(s) "X" "X" = PTH Clin Nephrol 1979;11:181-9.

3 Stickler GB, Bergen BJ. A review: short stature in renal disease. Pediatr Re 1973;7:978-82.

4 Slatopolsky E, Caglar S, Penell JP, et al. On the pathogenesis of hyperparathyroidism in chronic experimental renal insufficiency in the dog. $\mathcal{F}$ Clin Invest $1971 ; 50: 492-9$

5 Slatopolsky E, Caglar S, Gradowska J, et al. On the prevention of secondary hyperparathyroidism in experimental chronic renal disease using proportional reduction of dietary phosphorus intake. Kidney Int 1972;2:147-52.

Bourgoigne JJ, et al. Reversal of hyperparathyroidism in response to dietar

7 Poisson M, Masmaly R, Lebkiri B. Dialysis encephalopathy: recovery after inter-

8 Andreoli SP, Bergstein JM, Sherrand DJ. Aluminium intoxication from alu- 
minium containing phosphate binders in children with azotemia not undergoing hemodialysis. $N$ Engl f Med 1984;310:1079-84

9 Clarkson EM, McDonald SJ, De Wardener HE. The effect of a high intake of calcium carbonate in normal subjects and patients with chronic renal failure.
Clin Sci 1966;30:425-38.

10 Moriniere PH, Roussel A, Tahiri Y, et al. Substitution of aluminium hydroxide by high doses of calcium carbonate in patients on chronic haemodialysis (1) hyperalumininaemia and equal control

roidism. Proc Eur Dial Transplant Assoc $1982 ; 19: 784-7$.
11 Brown HE. The evaluation of a new diet for children on haemodialysis pro-

12 Walton RJ, Bijvoet OLM. Nomogram for the derivation of renal threshold phosphate concentration. Lancet $1975 ; \mathrm{ii}: 309-19$.

13 Bijvoet OLM. Indices for the measurement of the renal handling of phosphate. In: Massry SG, Fleisch $\mathrm{H}$, eds. Renal handling of phosphate. New York: Plenum Medical Book Co, 1980:1-37.

14 Woo J, Singer FR. Radioimmunoassay for human parathyroid hormone. Clin Chim Acta 1974;54:161-8.

15 Tovey KC, Oldham KG, Whelan JAM. A simple direct assay for cyclic AMP in lasma and other biological samples using an improved competitive protein binding techniqe. Clin Chim Acta 1974;56:221-34.

16 Lawrence R. Assay of serum inorganic phosphate without deproteinisation

17 Chantler C, Barratt TM. Estimation of glomerular filtration rate from plasma clearance of 51-chromium edetic acid. Arch Dis Child 1972;47:613-7.

18 Counahan R, Chantler C, Ghazali S, et al. Estimation of glomerular filtration rate from plasma creatinine concentration in children. Arch Dis Child 1976;51

19 Portale AA, Booth BE, Halloran BP, et al. Effect of dietary phosphorus on circulating concentrations of 1,25 dihydroxy vitamin $D$ and immunoreactive parathyroid horm $1984 ; 73: 1580-9$.
20 Bricker NS. On the pathogenesis of the uremic state: an exposition of the "tradeoff hypothesis." N Engl f Med 1972;286:1093-9.

21 Rutherford WE, Bordier P, Marie P, et al. Phosphate control and 25 hydroxycholecalciferol administration in preventing experimental renal osteodystrophy in the dog. $\mathcal{F}$ Clin Invest 1977;60:332-41.

22 Ibels LS, Alfrey AC, Haut $\mathrm{L}$, et al. Preservation of function in experimental renal disease by dietary restriction of phosphate. $N$ Engl $\mathcal{F}$ Med 1978;298:122-6. Llach F, Massry SG, Koffler A, et al. Secondary hyperparathyroidism in early renal CK A : RS, Ramos JM, et al. Effect ionixed calcium immunoreactive parathyroid hormone, and aluminium in chronic renal failure. $\mathrm{Br}$ Med $\mathcal{f} 1982 ; 284: 776-8$.

25 Brown EM, Wilson RE, Eastman RC, Pallotta J, Marynick S. Abnormal regulation of parathyroid hormone release by calcium in secondary hyperparathyroidism due to chronic renal failure. $\mathcal{F}$ Clin Endocrinol Metab 1982;84:172-9. 26 Nathan E, Pedersen S. Dialysis encephalopathy in a non-dialysed uraemic boy treated with aluminium hydroxide orally. Acta Paediatr Scand 1980;69:

Groswold WR, Reznik V, Mendoza A, et al. Accumulation of aluminium in a non-dialysed uremic child receiving aluminium hydroxide. Pediatrics 1983;

edman AB, Miller NL, Warady BA, Lunn GM, Alfrey AC. Aluminium loading in children with chronic renal failure. Kidney Int $1984 ; 26: 201-4$.

royer $\mathrm{M}$, Kleinknecht $\mathrm{C}$, Loriat $\mathrm{C}$, et al. Growth in children treated with long term hemodialysis. $\mathcal{F}$ Pediatr 1974;84:642-9.

30 Hodson EM, Shan PF, Evans RA, et al. Growth retardation and renal osteodystrophy in children with chronic renal failure. F Pediatr 1983;103:735-40.

31 Norman ME, Mazur AT, Borden IVS, et al. Early diagnosis of juvenile renal osteodystrophy. $\mathcal{F}$ Pediatr 1980;97:226-31.

Accepted 11 fune 1985)

\title{
Simple mechanical methods for cardioversion: defence of the precordial thump and cough version
}

\author{
G CALDWELL， G MILLAR， ELIZABETH QUINN， R VINCENT， D A CHAMBERLAIN
}

\begin{abstract}
A prospective study was made of the value of the precordial thump and of cough version in life threatening ventricular arrhythmias. Of about 5000 medical and surgical patients, 68 were treated for persistent ventricular tachycardia and 248 for ventricular fibrillation, 86 of whom had presented outside hospital. Mechanical intervention was successful in 26 incidents occurring in 23 patients. Electrocardiographic records were obtained in 14 instances. Ventricular fibrillation was terminated by a thump in five patients and ventricular tachycardia by either a thump or a cough in a total of 17 patients. Four additional instances were recorded of successful recovery from asystolic or unspecified circulatory arrest after a precordial thump. Fifteen patients survived to be dis-
\end{abstract} charged from hospital.

The potential benefit of the precordial thump and cough versions greatly outweighs their risks; hence these manoeuvres should probably be reintroduced into schedules for first aid resuscitation.

\section{Introduction}

Mechanical methods for treating cardiac arrest first attracted attention in 1920, when Schott reported that a blow to the chest restored the heart beat in a patient with an Adams-Stokes attack. ${ }^{1}$

Royal Sussex County Hospital, Brighton, East Sussex BN2 5BE G CALDWELL, BA, MRCP, registrar in medicine

G MILLAR, resuscitation technician

ELIZABETH QUINN, research assistant

$R$ VINCENT, MD, FRCP, consultant cardiologist

D A CHAMBERLAIN, MD, FRCP, consultant cardiologist

Correspondence to: Dr Chamberlain.
More recent reports have described both precordial thumps ${ }^{2}$ and coughing $^{3}$ for the reversion of ventricular tachycardia; precordial thumps may also be effective in ventricular fibrillation. ${ }^{4}{ }^{5}$

Precordial thumps were once recommended widely, but then awareness grew of the possible risk of converting ventricular tachycardia to ventricular fibrillation by such manoeuvres. ${ }^{5}$ The American Heart Association now recommends a precordial thump only at the onset of ventricular tachycardia or fibrillation for patients who are being monitored. ${ }^{6}$ This manoeuvre has been deleted entirely from British first aid manuals. ${ }^{7}$

Evidence for the effectiveness of these physical manoeuvres is often anecdotal. Moreover, the lack of electrocardiographic proof of their success has generated further scepticism. We therefore report our experience of cough and thump version documented as fully as possible in a prospective study carried out over one year from May 1983.

\section{Patients and methods}

The population studied comprised all patients-about 5000admitted to the cardiac care unit, the intensive care unit, or the general medical and surgical wards of this hospital together with any victim of sudden death occurring outside hospital in whom an attempt at resuscitation was made. Of this group, a little over 1000 patients were judged to be at risk of circulatory arrest.

From 1 May 1983 we recorded relevant information from all attempted resuscitations associated with ventricular tachycardia or fibrillation. Whenever possible electrocardiograms were obtained during resuscitation, but in many cases recordings could not be continued during therapeutic interventions.

Patients who were unconscious with cardiac arrest were given a precordial thump over the lower sternum. The initial treatment for ventricular tachycardia, or for ventricular fibrillation of recent onset in patients who were still conscious, was an instruction to cough. If this was unsuccessful a precordial thump was used after explanation to the patient. Subsequent treatment was continued on conventional lines with electrical cardioversion and drugs as appropriate.

We did not measure the force required for the precordial thump, but our practice was to give as firm a blow as possible from a height of $15 \mathrm{t}: 20 \mathrm{~cm}$ above the chest, directed at a point two thirds of the way down the sternum. 